\title{
ANALYSIS OF THE ABILITY OF LECTURERS IN THE USE OF ONLINE LEARNING MEDIA IN THE FACULTY OF TARBIYAH AND KEGURUAN (FTK) UIN AR-RANIRY BANDA ACEH
}

\author{
Fathiah $^{1 *}$, Nelli Raharti ${ }^{2}$, Muhammad Rizal Fachri ${ }^{3}$ \\ ${ }^{1,3}$ Universitas Islam Negeri Ar-Raniry Banda Aceh \\ ${ }^{2}$ Universitas Ubudiyah Indonesia \\ * Corresponding author E-mail: fathiah@ar-raniry.ac.id
}

\begin{abstract}
Keywords:
Learning media, online learning, ability

analysis, teaching, efficiency
\end{abstract}

\begin{abstract}
This study aims to describe lecturers' ability to use online learning media at the Tarbiyah and Keguruan Faculty of UIN Ar-Raniry Banda Aceh in the learning process. This study used a quantitative descriptive research design. Research subjects are lecturers who actively teach in the odd semester of 2020/2021. Meanwhile, 42 people were randomly selected as samples. Data collection was carried out using questionnaires and interviews. Data analysis used descriptive statistical analysis. The results showed that lecturers' ability with indicators of skills in using online learning media obtained an average value of $79.29 \%$, which means that, on average, the lecturers were able to use online learning media well. The ability of lecturers with indicators of skills in managing online learning is obtained an average value of $67.56 \%$, which means that the lecturer can manage online learning well.
\end{abstract}

\section{Introduction}

The Covid -19 pandemic that hit and spread worldwide resulted in paralyzed all central sectors, namely economic sectors around the world. The economic sector, the health sector, or the health sector have become a worldwide crisis, but it is also followed by other sectors [1], such as the education sector being affected [2]. All countries must take steps that have complicated implications for the country's socio-economic conditions [3].

Indonesia is one of the countries affected by the COVID-19 case, with 41,431 cases as of June 15, 2020. The mortality of COVID-19 cases in Indonesia is relatively higher than global cases, namely 5.49\% [4]. All regions in Indonesia have reported cases, including Aceh province, with several positive cases of COVID-19 based on the results of the Polymerase Chain Reaction (PCR) examination of 37 people.

The development of science and technology encourages efforts to encourage renewal efforts [5][6] in the use of technological results in the learning process [7][8]. So lecturers must use modern technology tools [9] or traditional and choose what media to use [10]. There is a possibility that these tools follow the developments and guidelines of the times [11][12]. At least it can use cheap and efficient tools [13][14], although it is simple but is a must in achieving the expected goals [15][16]. Besides being able to use the available tools [17][18], it is also required to develop skills in making learning media that will be used by these media which are not yet available [19][20]. For that, we must have sufficient knowledge and experience about instructional media [21][22].

Learning media is an intermediary that functions to convey learning messages [23][24]. Communication between teachers and students will not run well without media [25][26]. Advances in communication and technology [27][28], require the use of more innovative and creative learning media [29] in the learning process in schools [30]. There are four uses of instructional media in the teaching and learning process, namely: (1) clarifying the presentation of messages so that they are not verbalised, (2) Overcoming the limitations of space, time, and sensory power, (3) Using appropriate and varied learning media can overcome the passive attitude of students, (4). Provide stimulants, experiences, and the same perceptions for each student [31]. The use of instructional media in the teaching and learning process [32] can generate new desires and interests [33], generate motivation and stimulation of learning activities [34], and even have an 
influence on students [35]. Instructional media can also help students improve understanding [36][37], presenting interesting and reliable data [38][39].

Learning media is a means of interaction between lecturers and students so that learning activities are more effective and efficient [40][41]. Media can display information through sound, images, movement and colour, both natural and manipulated [42][43]; to learn media, it will be easier to achieve maximally with minimal time and effort [44]. The use of various media sources, one of which is courageous learning media [45], is expected to help students understand lecture material. Moreover, the condition of the Covid-19 pandemic in all campuses must learn with new methods [46][47], including students and lecturers who must learn bravely [48]. The ability of lecturers to use bold learning media during this pandemic [49] is expected to increase students' interest in learning and become a benchmark or success in brave learning [50][51]. Based on the description above, the writer tries to analyze lecturers' ability in learning with the title "Analysis of Ability in Using Online Learning Media at the Faculty of Tarbiyah and Keguruan, UIN Ar-Raniry Banda Aceh."

\section{Method}

This study aims to describe or describe the ability of lecturers to use online learning media. Therefore this type of research can be classified as descriptive research. The purpose of descriptive research is to describe what variables or conditions exist in a situation.

This research was conducted at the Faculty of Tarbiyah and Keguruan (FTK) UIN Ar-Raniry Banda Aceh in the odd semester 2020/2021. The subjects in this study were lecturers who actively taught in the odd semester of 2020/2021. Meanwhile, the samples in this study were 42 people who were randomly selected.

The data collection technique in this study used a questionnaire instrument that was distributed online using Google Form. Previously, the validity and reliability of the instrument were tested first. The questionnaire consisted of two indicators studied: skills in using online learning media and skills in managing online learning. These indicators are developed by researchers and described in the form of statements/questions. The data analysis technique uses a percentage description with the steps as follows:

- Calculating the respondent's value from each aspect or sub variable.

- Recap value.

- Calculate the average value.

- Calculating the percentage with the formula:

$$
D P=\frac{n}{N} \times 100
$$

Information:

DP $=$ Descriptive Percentage $(\%)$

$\mathrm{n}=$ empirical score (score obtained)

$\mathrm{N}=$ ideal score for each question item

After the percentage results are obtained, they are included in several criteria, as shown in Table 1 .

Table 1: Percentage Result Assessment Criteria

\begin{tabular}{|l|l|}
\hline Value Range & Criteria \\
\hline $81 \%-100 \%$ & Very good \\
\hline $61 \%-80 \%$ & Good \\
\hline $41 \%-60 \%$ & Passable \\
\hline $21 \%-40 \%$ & Poor \\
\hline $0 \%-20 \%$ & Not good \\
\hline
\end{tabular}

\section{Results and Discussion}

This research was conducted on lecturers who actively teach in the odd semester of 2020/2021 at the Tarbiyah and Keguruan of UIN Ar-Raniry, randomly selected 42 people. Data collection was carried out using a questionnaire instrument-an online questionnaire using Google Form. The questionnaire consisted of two indicators of the ability of the lecturers to be studied, namely the skills of using online learning media and courageous learning skills, where the indicators and the statements/questions developed by the researcher were tested for validity first using the Pearson Product Moment formula which was processed with the help of SPSS. A valid statement item over a tone of 0.3 and above. Also performed a reliability test using the Cronbach's alpha formula. The basis for the decision is that Cronbach's Alpha value criteria are> 0.60 , so all questions are declared reliable.

Table 2: Results of the Validity Test Analysis

\begin{tabular}{|l|l|l|}
\hline Item no & Correlation coefficient & Information \\
\hline 1 & 0,678 & Valid \\
\hline 2 & 0,619 & Valid \\
\hline 3 & 0,539 & Valid \\
\hline 4 & 0,546 & Valid \\
\hline 5 & 0,775 & Valid \\
\hline 6 & 0,457 & Valid \\
\hline 7 & 0,771 & Valid \\
\hline 8 & 0,774 & Valid \\
\hline 9 & 0,595 & Valid \\
\hline 10 & 0,751 & Valid \\
\hline 11 & 0,316 & Valid \\
\hline 12 & 0,743 & Valid \\
\hline 13 & 0,315 & Valid \\
\hline
\end{tabular}


Based on table 2, it can be seen that the $\mathrm{r}$ value for all items is greater than 0.30 . It can be concluded that all instrument items used in this study are valid.

Table 3: Reliability Test Analysis Results

\begin{tabular}{|c|c|}
\hline Cronbach's Alpha & N of Items \\
\hline .772 & 13 \\
\hline
\end{tabular}

Based on the output above, it can be seen that the Cronbach's Alpha value of 0.772 is greater than 0.60 ; it can be concluded that all instrument items used in this study are reliable.

The following is the Tabulation of Research Data for indicators of skills in using learning media, courage and organizational skills for learning courage.

Table 4: The score of the results of the questionnaire on skills in using bold learning media

\begin{tabular}{|c|c|c|c|c|c|c|}
\hline \multirow{2}{*}{$\begin{array}{l}\text { Receipt } \\
\text { Number }\end{array}$} & \multicolumn{5}{|c|}{ Score Item Number } & \multirow[t]{2}{*}{ amount } \\
\hline & 1 & 2 & 3 & 4 & 5 & \\
\hline 1 & 3 & 4 & 4 & 4 & 4 & 29 \\
\hline 2 & 3 & 3 & 3 & 3 & 3 & 19 \\
\hline 3 & 3 & 3 & 4 & 2 & 3 & 15 \\
\hline 4 & 4 & 3 & 3 & 3 & 3 & 15 \\
\hline 5 & 3 & 3 & 3 & 3 & 3 & 16 \\
\hline 6 & 3 & 2 & 4 & 2 & 2 & 15 \\
\hline 7 & 3 & 2 & 2 & 2 & 1 & 13 \\
\hline 8 & 3 & 3 & 3 & 3 & 3 & 10 \\
\hline 9 & 4 & 4 & 4 & 4 & 3 & 15 \\
\hline 10 & 3 & 3 & 3 & 3 & 3 & 19 \\
\hline 11 & 4 & 4 & 3 & 4 & 3 & 15 \\
\hline 12 & 3 & 3 & 3 & 3 & 3 & 18 \\
\hline 13 & 4 & 4 & 4 & 4 & 3 & 15 \\
\hline 14 & 3 & 3 & 4 & 3 & 3 & 19 \\
\hline 15 & 3 & 3 & 3 & 3 & 3 & 16 \\
\hline 16 & 4 & 3 & 4 & 4 & 4 & 15 \\
\hline 17 & 4 & 3 & 4 & 3 & 4 & 19 \\
\hline 18 & 4 & 4 & 3 & 3 & 3 & 18 \\
\hline 19 & 4 & 3 & 4 & 3 & 4 & 17 \\
\hline 20 & 4 & 3 & 3 & 3 & 4 & 18 \\
\hline 21 & 3 & 4 & 2 & 3 & 3 & 17 \\
\hline 22 & 2 & 3 & 3 & 1 & 2 & 15 \\
\hline 23 & 3 & 2 & 3 & 3 & 3 & 11 \\
\hline 24 & 4 & 3 & 2 & 3 & 3 & 14 \\
\hline 25 & 3 & 3 & 3 & 2 & 3 & 15 \\
\hline 26 & 3 & 3 & 3 & 3 & 3 & 14 \\
\hline 27 & 2 & 2 & 2 & 4 & 2 & 15 \\
\hline 28 & 4 & 2 & 3 & 4 & 4 & 12 \\
\hline 29 & 4 & 4 & 4 & 3 & 4 & 17 \\
\hline 30 & 3 & 2 & 3 & 2 & 2 & 19 \\
\hline 31 & 3 & 3 & 4 & 3 & 3 & 12 \\
\hline 32 & 4 & 1 & 3 & 3 & 3 & 16 \\
\hline 33 & 3 & 3 & 3 & 2 & 3 & 14 \\
\hline 34 & 4 & 4 & 4 & 3 & 3 & 14 \\
\hline 35 & 3 & 2 & 3 & 3 & 3 & 18 \\
\hline 36 & 3 & 3 & 3 & 3 & 3 & 14 \\
\hline 37 & 3 & 3 & 3 & 3 & 3 & 15 \\
\hline 38 & 4 & 3 & 2 & 3 & 3 & 15 \\
\hline 39 & 4 & 3 & 3 & 3 & 3 & 15 \\
\hline 40 & 3 & 3 & 2 & 3 & 3 & 16 \\
\hline 41 & 4 & 4 & 3 & 3 & 4 & 14 \\
\hline \multirow[t]{2}{*}{42} & 4 & 2 & 4 & 3 & 4 & 18 \\
\hline & 144 & 128 & 137 & 134 & 140 & 666 \\
\hline
\end{tabular}

Table 5: The Data on Skills in Using Online Learning Media

\begin{tabular}{|c|c|c|c|c|c|}
\hline \multicolumn{5}{|c|}{ Item score } & \multirow{2}{*}{ Percentage } \\
\hline 1 & 2 & 3 & 4 & 5 & \\
\hline $85,71 \%$ & $76,19 \%$ & $81,55 \%$ & $79,76 \%$ & $83,33 \%$ & $81,31 \%$ \\
\hline
\end{tabular}

Based on data analysis on the indicator of lecturers' ability, namely the skills of lecturers in using online learning media, the following data were obtained:

From the results of the analysis of the questionnaire answer sheets filled out by 42 lecturers who answered the 5 questions given, each item consists of 4 answer choices. The maximum score $=4 \times 42=168$ and the minimum score $=1 \times 42$ is obtained. $=42$. The results obtained are statement 1 totalling 144 with a percentage of $85.71 \%$, statement 2 totalling 128 with a percentage of $76.19 \%$, statement 3 totalling 137 with a percentage of $81.55 \%$, statement 4 totalling 134 with a percentage of $79,76 \%$, statement 5 amounted to 140 with a percentage of $83,33 \%$. While the number of ideal scores (criteria) for all items $=4 \times 5 \times 42=840$. The highest score for each item $=4$, the number of items $=5$ and the number of respondents $=42$. The total score obtained from the results of data collection $=666$ 
Based on the data obtained regarding lecturers' ability with indicators of skills in using online learning media, the average value is obtained $=666: 840 \times 100=79,29 \%$. So the average value is $79.29 \%$ in the good category. Thus it can be concluded that the average lecturer can use online learning media well.

Table 6: Score the results of the online learning management skills questionnaire

\begin{tabular}{|c|c|c|c|c|c|c|c|c|c|}
\hline \multirow{2}{*}{$\begin{array}{l}\text { Receipt } \\
\text { Number }\end{array}$} & \multicolumn{8}{|c|}{ Score for item } & \multirow[t]{2}{*}{ Amount } \\
\hline & 6 & 7 & 8 & 9 & 10 & 11 & 12 & 13 & \\
\hline 1 & 3 & 1 & 2 & 3 & 2 & 3 & 2 & 2 & 18 \\
\hline 2 & 3 & 3 & 3 & 2 & 3 & 3 & 3 & 3 & 23 \\
\hline 3 & 3 & 3 & 2 & 3 & 2 & 4 & 3 & 1 & 21 \\
\hline 4 & 3 & 2 & 2 & 3 & 3 & 4 & 3 & 2 & 22 \\
\hline 5 & 3 & 2 & 2 & 1 & 2 & 3 & 2 & 3 & 18 \\
\hline 6 & 3 & 4 & 2 & 2 & 2 & 4 & 2 & 1 & 20 \\
\hline 7 & 3 & 2 & 2 & 2 & 2 & 3 & 2 & 3 & 19 \\
\hline 8 & 3 & 3 & 3 & 2 & 3 & 2 & 2 & 1 & 19 \\
\hline 9 & 3 & 4 & 4 & 3 & 4 & 2 & 4 & 2 & 26 \\
\hline 10 & 3 & 2 & 2 & 3 & 2 & 4 & 2 & 3 & 21 \\
\hline 11 & 4 & 4 & 3 & 3 & 3 & 4 & 4 & 3 & 28 \\
\hline 12 & 3 & 3 & 3 & 3 & 3 & 3 & 3 & 3 & 24 \\
\hline 13 & 3 & 4 & 4 & 3 & 3 & 4 & 4 & 3 & 28 \\
\hline 14 & 3 & 3 & 3 & 3 & 2 & 3 & 3 & 2 & 22 \\
\hline 15 & 3 & 3 & 3 & 3 & 3 & 4 & 3 & 2 & 24 \\
\hline 16 & 3 & 2 & 2 & 3 & 2 & 1 & 3 & 3 & 19 \\
\hline 17 & 3 & 3 & 3 & 3 & 2 & 4 & 3 & 3 & 24 \\
\hline 18 & 3 & 2 & 2 & 2 & 2 & 4 & 2 & 3 & 20 \\
\hline 19 & 3 & 4 & 4 & 3 & 3 & 3 & 3 & 3 & 26 \\
\hline 20 & 3 & 2 & 3 & 3 & 3 & 4 & 3 & 2 & 23 \\
\hline 21 & 3 & 2 & 2 & 3 & 2 & 3 & 2 & 2 & 19 \\
\hline 22 & 3 & 1 & 1 & 1 & 1 & 4 & 2 & 3 & 16 \\
\hline 23 & 3 & 2 & 3 & 1 & 3 & 3 & 2 & 1 & 18 \\
\hline 24 & 3 & 4 & 3 & 2 & 2 & 2 & 3 & 3 & 22 \\
\hline 25 & 3 & 2 & 1 & 2 & 2 & 1 & 1 & 3 & 15 \\
\hline 26 & 3 & 3 & 3 & 2 & 2 & 3 & 3 & 3 & 22 \\
\hline 27 & 4 & 3 & 4 & 3 & 3 & 3 & 4 & 2 & 26 \\
\hline 28 & 4 & 4 & 4 & 3 & 4 & 4 & 3 & 2 & 28 \\
\hline 29 & 3 & 1 & 3 & 1 & 2 & 3 & 4 & 1 & 18 \\
\hline 30 & 3 & 2 & 1 & 2 & 2 & 3 & 2 & 1 & 16 \\
\hline 31 & 3 & 1 & 3 & 3 & 2 & 4 & 2 & 1 & 19 \\
\hline 32 & 3 & 2 & 3 & 1 & 2 & 3 & 3 & 1 & 18 \\
\hline 33 & 3 & 3 & 3 & 3 & 3 & 3 & 3 & 2 & 23 \\
\hline 34 & 3 & 2 & 3 & 3 & 2 & 1 & 3 & 3 & 20 \\
\hline 35 & 3 & 2 & 3 & 3 & 2 & 3 & 3 & 3 & 22 \\
\hline 36 & 3 & 2 & 2 & 3 & 2 & 4 & 2 & 1 & 19 \\
\hline 37 & 3 & 3 & 3 & 3 & 3 & 4 & 3 & 3 & 25 \\
\hline 38 & 3 & 3 & 2 & 3 & 3 & 4 & 3 & 3 & 24 \\
\hline 39 & 3 & 3 & 4 & 3 & 3 & 4 & 3 & 2 & 25 \\
\hline 40 & 2 & 2 & 2 & 3 & 2 & 4 & 2 & 2 & 19 \\
\hline 41 & 3 & 3 & 3 & 3 & 3 & 4 & 3 & 2 & 24 \\
\hline 42 & 3 & 3 & 4 & 3 & 3 & 3 & 3 & 3 & 25 \\
\hline & 141 & 123 & 129 & 123 & 121 & 154 & 134 & 115 & 908 \\
\hline
\end{tabular}

Table 7: Percentage of online learning management skills data

\begin{tabular}{|c|c|c|c|c|c|c|c|c|}
\hline \multicolumn{8}{|c|}{ Score for item } & Amount \\
\hline 6 & 7 & 8 & 9 & 10 & 11 & 12 & 13 & \\
\hline $83,93 \%$ & $73,21 \%$ & $76,79 \%$ & $73,21 \%$ & $72,02 \%$ & $91,67 \%$ & $79,76 \%$ & $68,45 \%$ & 77,38 \\
\hline
\end{tabular}

Based on data analysis on the lecturer ability indicator, namely the skills to manage online learning, the following data were obtained:

From the analysis results of the questionnaire answer sheets filled out by 42 lecturers who answered the 8 questions given, each item consists of 4 answer choices. The maximum score $=4 \times 42=168$ and the minimum score $=1 \times 42$ is obtained. $=42$. The results obtained are statement 6 totalling 141 with a percentage of $83.93 \%$, statement 7 amounting to 123 with a percentage of $73.21 \%$, statement 8 amounting to 129 with a percentage of $76.79 \%$, statement 9 amounting to 123 with a percentage of $73.21 \%$, statement 10 amounts to 121 with a percentage of $72.02 \%$. Statement 11 amounts to 154 with a percentage of $91,67 \%$, statement 12 amounts to 134 with $79,76 \%$ and statement 13 amounts to 115 with a percentage of $68,45 \%$. While the number of ideal scores (criteria) for all items $=4 \times 8 \times 42=$ 1344 , where the highest score for each item $=4$, the number of items $=8$ and the number of respondents $=42$. The total score obtained from the results of data collection $=908$

Based on the data obtained regarding lecturers' ability with indicators of online learning management skills, the average value is obtained $=908: 1344 \times 100=67.56 \%$. So the average value of $67.56 \%$ is included in the good category. Thus it can be concluded that lecturers have been able to manage online learning well. 


\section{Conclusion}

The conclusions obtained from the results of these studies are

- Based on the results and discussion, it can be concluded that the ability of lecturers with indicators of skills in using online learning media is in the good category with an average score of $79,29 \%$, which means that on average, the lecturers can use online learning media well.

- Based on the results and discussion, it can be concluded that the ability of lecturers with indicators of skills in managing online learning is in the good category with an average value of $67.56 \%$, which means that on average, the lecturers have been able to manage online learning well.

\section{Acknowledgement}

This research was conducted in collaboration with researchers from Ar-Raniry State Islamic University Banda Aceh and Universitas Ubudiyah Indonesia. It is hoped that this research can contribute to universities and other researchers as a reference and further development. Thanks to all those who participated in completing this research.

\section{References}

[1] E. Chung, G. Subramaniam, and L. C. Dass, “Online learning readiness among university students in Malaysia amidst Covid-19," Asian J. Univ. Educ., vol. 16, no. 2, 2020, doi: 10.24191/AJUE.V16I2.10294.

[2] C. Dong, S. Cao, and H. Li, "Young children's online learning during COVID-19 pandemic: Chinese parents' beliefs and attitudes," Child. Youth Serv. Rev., vol. 118, 2020, doi: 10.1016/j.childyouth.2020.105440.

[3] K. Mukhtar, K. Javed, M. Arooj, and A. Sethi, "Advantages, limitations and recommendations for online learning during covid-19 pandemic era," Pakistan J. Med. Sci., vol. 36, no. COVID19-S4, 2020, doi: 10.12669/pjms.36.COVID19-S4.2785.

[4] A. Population, "Population by Country (2020) - Worldometer," Worldometer, 2020.

[5] S. Mehall, "Purposeful interpersonal interaction in online learning: What is it and how is it measured?," Online Learn. J., vol. 24, no. 1, 2020, doi: 10.24059 /olj.v24i1.2002.

[6] J. C. Liu, "Evaluating online learning orientation design with a readiness scale," Online Learn. J., vol. 23, no. 4, 2019, doi: 10.24059/olj.v23i4.2078.

[7] E. Randazzo, E. Niklasson, and A. Mordvintsev, "MPLP: Learning a message passing learning protocol," arXiv. 2020.

[8] J. Febrian Rusdi et al., "ICT Research in Indonesia," 2019.

[9] J. A. Howell, L. D. Roberts, and V. O. Mancini, "Learning analytics messages: Impact of grade, sender, comparative information and message style on student affect and academic resilience," Comput. Human Behav., vol. 89, 2018, doi: 10.1016/j.chb.2018.07.021.

[10] L. Y. Nie, C. Gao, Z. Zhong, W. Lam, Y. Liu, and Z. Xu, "Contextualized Code Representation Learning for Commit Message Generation," arXiv. 2020.

[11] J. H. Kuznekoff, S. Munz, and S. Titsworth, "Mobile Phones in the Classroom: Examining the Effects of Texting, Twitter, and Message Content on Student Learning," Commun. Educ., vol. 64, no. 3, 2015, doi: 10.1080/03634523.2015.1038727.

[12] S. Widodo and Wahyudin, "Selection of Learning Media Mathematics for Junior School Students," Turkish Online J. Educ. Technol. - TOJET, vol. 17 , no. 1,2018

[13] S. Huda, R. A. Sholikhakh, N. S. Bina, F. Lestari, B. Habibi, and P. Suharso, "Effect of application smart circuit learning media to mathematics learning outcomes: A case study of Islamic School Students," J. Educ. Gift. Young Sci., vol. 7, no. 3, 2019, doi: 10.17478/jegys.597053.

[14] H. C. Wei and C. Chou, "Online learning performance and satisfaction: do perceptions and readiness matter?," Distance Educ., vol. 41, no. 1, 2020, doi: $10.1080 / 01587919.2020 .1724768$

[15] N. Sudarwati and Rukminingsih, "Evaluating e-learning as a learning media a case of entrepreneurship e-learning using schoology as media," Int. J. Emerg. Technol. Learn., vol. 13, no. 9, 2018, doi: 10.3991/ijet.v13i09.7783.

[16] R. Hardi, "Genetic algorithm in solving the TSP on these mineral water," 2015, doi: 10.1109/ISITIA.2015.7220008.

[17] M. Sholihin, R. C. Sari, N. Yuniarti, and S. Ilyana, "A new way of teaching business ethics: The evaluation of virtual reality-based learning media," Int. J. Manag. Educ., vol. 18, no. 3, 2020, doi: 10.1016/j.ijme.2020.100428.

[18] R. K. Dewi, S. Wardani, N. Wijayati, and W. Sumarni, "Demand of ICT-based chemistry learning media in the disruptive era," Int. J. Eval. Res. Educ., vol. 8, no. 2, 2019, doi: 10.11591/ijere.v8i2.17107.

[19] R. A. Carter, M. Rice, S. Yang, and H. A. Jackson, "Self-regulated learning in online learning environments: strategies for remote learning," Inf. Learn. Sci., vol. 121, no. 5-6, 2020, doi: 10.1108/ILS-04-2020-0114.

[20] H. C. Rhim and H. Han, "Teaching online: Foundational concepts of online learning and practical guidelines," Korean Journal of Medical Education, vol. 32, no. 2. 2020, doi: 10.3946/KJME.2020.171.

[21] N. Nofrion and B. Wijayanto, "LEARNING ACTIVITIES IN HIGHER ORDER THINKING SKILL (HOTS) ORIENTED LEARNING CONTEXT," Geosfera Indones., vol. 3, no. 2, 2018, doi: 10.19184/geosi.v3i2.8126.

[22] O. B. Adedoyin and E. Soykan, "Covid-19 pandemic and online learning: the challenges and opportunities," Interactive Learning Environments. 2020, doi: 10.1080/10494820.2020.1813180.

[23] R. A. Liliana, W. Raharjo, I. Jauhari, and D. Sulisworo, "Effects of the online interactive learning media on student's achievement and interest in physics," Univers. J. Educ. Res., vol. 8, no. 3 B, 2020, doi: 10.13189/ujer.2020.081507.

[24] K. Do, T. Tran, T. Nguyen, and S. Venkatesh, "Attentional multilabel learning over graphs: a message passing approach," Mach. Learn., vol. 108, no. 10, 2019, doi: 10.1007/s10994-019-05782-6.

[25] B. E. Dasilva et al., "Development of Android-based Interactive Physics Mobile Learning Media (IPMLM) with scaffolding learning approach to improve HOTS of high school students," J. Educ. Gift. Young Sci., vol. 7, no. 3, 2019, doi: 10.17478/jegys.610377.

[26] "Development of Augmented Reality Technology Based Learning Media of Lathe Machines," J. Pendidik. Teknol. dan Kejuru., vol. 24, no. 1, 2018, doi: 10.21831/jptk.v24i1.18245.

[27] F. Martin, T. Sun, and C. D. Westine, "A systematic review of research on online teaching and learning from 2009 to 2018," Comput. Educ., vol. 159, 2020, doi: 10.1016/j.compedu.2020.104009.

[28] A. Nurwijayanti, Budiyono, and L. Fitriana, "Combining google sketchup and ispring suite 8: A breakthrough to develop geometry learning media," J. Math. Educ., vol. 10, no. 1, 2019, doi: 10.22342/jme.10.1.5380.103-116.

[29] I. M. Astra, H. Nasbey, and A. Nugraha, "Development of an android application in the form of a simulation lab as learning media for senior high school students," Eurasia J. Math. Sci. Technol. Educ., vol. 11, no. 5, 2015, doi: 10.12973/eurasia.2015.1376a.

[30] E. K. Wati and N. Widiansyah, "Design of learning media: Modeling \& simulation of building thermal comfort optimization system in building physics course," J. Pendidik. IPA Indones., vol. 9, no. 2, 2020, doi: 10.15294/jpii.v9i2.23504.

[31] Y. Zhu, J. H. Zhang, W. Au, and G. Yates, "University students' online learning attitudes and continuous intention to undertake online courses: 
D. Shen, M. H. Cho, C. L. Tsai, and R. Marra, "Unpacking online learning experiences: Online learning self-efficacy and learning satisfaction," Internet High. Educ., vol. 19, 2013, doi: 10.1016/j.iheduc.2013.04.001.

[33] S. C. H. Hoi, D. Sahoo, J. Lu, and P. Zhao, “Online learning: A comprehensive survey," arXiv. 2018.

[34] D. O’Doherty, M. Dromey, J. Lougheed, A. Hannigan, J. Last, and D. McGrath, "Barriers and solutions to online learning in medical education - An integrative review," BMC Medical Education, vol. 18, no. 1. 2018, doi: 10.1186/s12909-018-1240-0.

[35] F. Martin, B. Stamper, and C. Flowers, "Examining student perception of readiness for online learning: Importance and confidence," Online Learn. J., vol. 24, no. 2, 2020, doi: 10.24059/olj.v24i2.2053.

[36] N. Yuniarti, A. L. Setiawan, and D. Hariyanto, "The development and comprehensive evaluation of control system training kit as a modularbased learning media," TEM J., vol. 9, no. 3, 2020, doi: 10.18421/TEM93-52.

[37] H. Kauffman, "A review of predictive factors of student success in and satisfaction with online learning," Research in Learning Technology, vol. 23. 2015, doi: 10.3402/rlt.v23.26507.

[38] S. Nuanmeesri and S. Jamornmongkolpilai, "The Development of the Virtual Learning Media of the Sacred Object Artwork," TOJET Turkish Online J. Educ. Technol., vol. 17, no. 1, 2018.

[39] S. Irmawan, Suharno, and H. Saputro, "Development of mobile learning media (Mlm) to enchance students' understanding of cnc programming subjects," Int. J. Adv. Trends Comput. Sci. Eng., vol. 9, no. 5, 2020, doi: 10.30534/ijatcse/2020/158952020.

[40] A. S. Sari and I. W. K. Wati, "Visibility of Learning Media of a Culinary-Based Electronic Magazine in Blended Learning," J. Pendidik. Teknol. dan Kejuru., vol. 26, no. 1, 2020.

[41] A. Apriliani, A. Asib, and U. Sebelas Maret Surakarta, "SCHOOLOGY AS A LEARNING MEDIA PLATFORM FOR WRITING SKILL," ELLiC, vol. 3, 2019

[42] L. WitaHarahap and E. Surya, "Development of learning media in mathematics for students with special needs," Int. J. Sci. Basic Appl. Res., vol. 33, no. 3, 2017.

[43] E. Sudarmilah, N. Ustia, and D. N. Bakhtiar, "Learning Media based on Augmented Reality Game," Int. J. Eng. Technol., vol. 8, no. 1.1, 2019.

[44] C. Hadza, A. Sesrita, and I. Suherman, "DEVELOPMENT OF LEARNING MEDIA BASED ON ARTICULATE STORYLINE," Indones. J. Appl. Res., vol. 1, no. 2, 2020, doi: 10.30997/ijar.v1i2.54.

[45] A. Febliza and O. Okatariani, "The Development of Online Learning Media by Using Moodle for General Chemistry Subject," J. Educ. Sci. Technol., vol. 6, no. 1, 2020, doi: 10.26858/est.v6i1.12339.

[46] P. T. Febrianto, S. Mas'udah, and L. A. Megasari, "Implementation of online learning during the covid-19 pandemic on Madura Island, Indonesia," Int. J. Learn. Teach. Educ. Res., vol. 19, no. 8, 2020, doi: 10.26803/ijlter.19.8.13.

[47] E. M. Mulenga and J. M. Marbán, "Prospective teachers' online learning mathematics activities in the age of COVID-19: A cluster analysis approach," Eurasia J. Math. Sci. Technol. Educ., vol. 16, no. 9, 2020, doi: 10.29333/EJMSTE/8345.

[48] L. N. Amali, N. Zees, and S. Suhada, "MOTION GRAPHIC ANIMATION VIDEO AS ALTERNATIVE LEARNING MEDIA," Jambura J. Informatics, vol. 2, no. 1, 2020, doi: 10.37905/jiji.v2i1.4640.

[49] K. Syauqi, S. Munadi, and M. B. Triyono, "Students' perceptions toward vocational education on online learning during the COVID-19 pandemic," Int. J. Eval. Res. Educ., vol. 9, no. 4, 2020, doi: 10.11591/ijere.v9i4.20766.

[50] Rasmitadila et al., "The perceptions of primary school teachers of online learning during the covid-19 pandemic period: A case study in Indonesia," J. Ethn. Cult. Stud., vol. 7, no. 2, 2020, doi: 10.29333/ejecs/388.

[51] R. E. Mayer, "Thirty years of research on online learning," Appl. Cogn. Psychol., vol. 33, no. 2, 2019, doi: 10.1002/acp.3482. 